\title{
AKAPDB: A-Kinase Anchoring Proteins Database
}

\section{In-Sil Kim ${ }^{1,2}$, Kyung-Joon Lim,2, Bok-Ghee $\mathrm{Han}^{4}$, Myung-Guen Chung ${ }^{4 *}$ and Kyu-Won $\mathrm{Kim}^{1,2,3_{*}}$}

\begin{abstract}
${ }^{1}$ Neurovascular Coordination Research Center, College of Pharmacy and Research Institute of Pharmaceutical Science, Seoul National University, Seoul 151-742, Korea, ${ }^{2}$ Interdisciplinary Program in Bioinformatics, Seoul National University, Seoul 151-742, Korea, ${ }^{3}$ Department of Molecular Medicine and Biopharmaceutical Sciences, Graduate School of Convergence Science and Technology, Seoul National University, Seoul 151-742, Korea, ${ }^{4}$ Center for Genome Science, National Institute of Health, Korea Center for Disease Control and Prevention, Seoul 122-701, Korea
\end{abstract}

\begin{abstract}
A-kinase-anchoring proteins (AKAPs) are scaffold proteins which compartmentalize protein kinase A (PKA, cAMP-dependent protein kinase) and other enzymes to specific subcellular sites. The spatiotemporal control of these enzymes by AKAPs is important for cellular function like cell growth and development etc. Hence, it is important to understand the basic function of AKAPs and their functional domains. However, diverse names, function, cellular localizations and many members of AKAPs increase difficulties when researchers search appropriate AKAPs for their experimental purpose. Nevertheless, there was no previous AKAPs-related database regardless of their important cellular functions and difficulty of finding appropriate AKAPs. So, we developed AKAPs database (AKAPDB), which contains their sequence information, functions and other information derived from prediction programs and other databases. Therefore, we propose that AKAPDB can be an important tool to researchers in the related fields. AKAPDB is available via the internet at http://plaza3.snu.ac.kr/akapdb/
\end{abstract}

Keywords: a-kinase anchoring protein, database

\section{Introduction}

Cellular regulation is controlled by the opposing actions

*Corresponding author: E-mail qwonkim@plaza.snu.ac.kr

Tel +82-2-880-6988, Fax +82-2-885-1827

E-mail aobo@chollian

Tel +82-2-380-2283, Fax +82-2-354-1068

Accepted 22 May 2010 of protein kinases and phosphatases (Scott and Pawson, 2000). The spatiotemporal control of these enzymes by AKAPs is important to metabolism, gene transcription, ion channel conductivity, cell growth, cell division and actin cytoskeleton rearrangements (Francis et al., 1994; Scott, 1991). AKAPs are functionally similar, but structurally diverse protein family which can be classified on the basis of their ability to bind to PKA holoenzyme inside cells (Colledge et al., 1999; Rubin, 1994). In spite of their structural diversity, AKAPs exist in many eukaryotic species, including humans, mice, rats, zebrafish, C.elegance and even yeast. All AKAPs share three common features: first, they have a PKA-anchoring domain: second, they have unique subcellular localization domains that target them to specific sites; third, they bind other signaling molecules to form multi-protein complexes (Wong et al., 2004).

Moreover, AKAPs have been reported to have diverse names, function, cellular localizations and many members of wide range of species. Accordingly, it is rapidly increasing in difficulties to search each appropriate AKAP for specific purpose. However, there is not AKAPs-related database regardless of their important cellular function and difficulty of finding appropriate AKAPs.

Therefore, we developed AKAPDB as secondary database which focuses on a specific topic using from the primary database and other literature sources (Bishop, 1999). AKAPDB provides sequence information and diverse function of AKAPs in all reported eukaryotic species. It contains putative phosphorylation sites, functionally important domains and cellular localizations derived from prediction programs and other databases. In addition, it provides predicted zebrafish AKAP partial sequences which can be used for morpholino-induced zebrafish reverse genetics. Morpholinos, chemically modified antisense oligonucleotides ( $\sim 25$ bases) which bind and block their specific target mRNA, are an easy and efficient technology of zebrafish target-selected functional study (Nasevicius et al., 2000). So, AKAPDB provides biologists with information which can be used to the efficient setup of experiments. AKAPDB can be useful to researchers by providing AKAPs information and integrated understanding of these diverse proteins.

\section{Methods}

\section{Data acquisition}

Raw data and information for AKAPDB were collected from a primary database such as NCBI. And the pub- 
lished scientific literatures resulted from queries with the terms 'A-kinase-anchoring proteins' and 'AKAP' were collected from PubMed (Wheeler et al., 2003) and Google Scholar. Articles that have been identified to contain information suitable for the database were used to serve as the primary source for data in AKAPDB.

Basic information, such as 'Official symbol', 'Preferred Names', 'Other names', 'Organism', 'Function', 'mRNA', and 'Protein', were collected from NCBI. Cellular localization of AKAPs was collected from LOCATE (Fink et al., 2006) and eSLDB (Pierleoni et al., 2006). And GPS 2.1 (Xue et al., 2008; Xue and Ren, 2009) served phosphorylation site which is important for function of AKAPs. SMART (Letunic et al., 2008) provides the prediction of domain. In addition, the predicted zebrafish AKAP partial sequences were derived from MegaBLAST (Wheeler et al., 2006). AKAPDB focuses on the diverse protein function and cellular location.

\section{Queries and visualization}

The records of AKAPDB consisted of diverse AKAPs. Each of them contained 16 fields, including information on name, cellular localization, function, species, mRNA sequence, protein sequence, putative phosphorylation site and predicted zebrafish AKAP partial sequences. Therefore, users can retrieve the data corresponding with names, Gene IDs, Protein IDs and species.

\section{Data fields}

Structure of data is made up 'Isoforms', 'Gene ID',
'Official symbol', 'Function', 'Preferred Names', 'Other names', 'Cellular localizations', 'Organism', 'mRNA ID', 'mRNA sequence', 'mRNA length', 'Protein ID', 'Protein sequence', 'Protein length' and 'Putative zebrafish AKAP'. The 'Cellular localizations' field represents the functional location of AKAPs in a cell. The 'Putative phosphorylation site' field serves the functionally important domains of AKAPs. And the 'Domain prediction' field represents a possible functional region. Also the 'Putative zebrafish AKAP' field provides potential zebrafish AKAP sequences. These fields are linked to NCBI for any additional information.

Table 1. Number of AKAPs of each species in the AKAPDB

\begin{tabular}{lc}
\hline \multicolumn{1}{c}{ Species } & No. of AKAPs \\
\hline Homo sapiens & 41 \\
Danio rerio & 38 \\
Rattus norvegicus & 30 \\
Mus musculus & 29 \\
Pan troglodytes & 18 \\
Bos taurus & 17 \\
Drosophila melanogaster & 15 \\
Macaca mulatta & 15 \\
Gallus gallus & 12 \\
Equus caballus & 11 \\
Ornithorhynchus anatinus & 10 \\
etc. & 264 \\
\hline Total & 500 \\
\hline
\end{tabular}

\section{AKAP DB}

HOME AKAP? SEARCH LINK HELP CONTACT US

A-Kinase anchoring protein: Database

AKAP8L Search

ex) Official symbol, Gene IDs, Protein IDs, Species

\begin{tabular}{|c|c|c|c|c|c|}
\hline \multicolumn{2}{|c|}{ Organism Official symbol } & \multirow{2}{*}{$\begin{array}{c}\text { Preferred Names } \\
\text { A kinase (PRKA) anchor } \\
\text { protein 8-like }\end{array}$} & \multirow{2}{*}{$\begin{array}{c}\text { Gene } \\
\text { ID } \\
26993\end{array}$} & \multirow{2}{*}{$\begin{array}{l}\text { mRNA ID } \\
\text { NM_014371 }\end{array}$} & \multirow{2}{*}{$\begin{array}{l}\text { Protein ID } \\
\text { NP_055186 }\end{array}$} \\
\hline $\begin{array}{l}\text { Homo } \\
\text { sapiens }\end{array}$ & AKAP8L & & & & \\
\hline $\begin{array}{l}\text { Mus } \\
\text { musculus }\end{array}$ & Akap8I & $\begin{array}{c}\text { A kinase (PRKA) anchor } \\
\text { protein } 8 \text {-like }\end{array}$ & 54194 & NM_017476 & NP_059504 \\
\hline $\begin{array}{l}\text { Rattus } \\
\text { norvegicus }\end{array}$ & Akap8I & $\begin{array}{c}\text { A kinase (PRKA) anchor } \\
\text { protein } 8 \text {-like }\end{array}$ & 299569 & 9 NM_001013946 & NP_001013968 \\
\hline $\begin{array}{l}\text { Canis } \\
\text { lupus } \\
\text { familiaris }\end{array}$ & AKAP8L & $\begin{array}{c}\text { A kinase (PRKA) anchor } \\
\text { protein } 8 \text {-like }\end{array}$ & 612946 & 6 XM_847928 & $X P_{-} 853021$ \\
\hline $\begin{array}{l}\text { Macaca } \\
\text { mulatta }\end{array}$ & AKAP8L & $\begin{array}{c}\text { A kinase (PRKA) anchor } \\
\text { protein } 8 \text {-like }\end{array}$ & 719202 & 2 XM_001113053 & B XP_001113053 \\
\hline $\begin{array}{l}\text { Bos } \\
\text { taurus }\end{array}$ & AKAP8L & $\begin{array}{c}\text { A kinase (PRKA) anchor } \\
\text { protein } 8 \text {-like }\end{array}$ & 539700 & 0 XM_864732 & XP_869825 \\
\hline $\begin{array}{l}\text { Pan } \\
\text { troglodytes }\end{array}$ & AKAP8L & $\begin{array}{c}\text { A kinase (PRKA) anchor } \\
\text { protein } 8 \text {-like }\end{array}$ & 455795 & 5 XM_512453 & XP_512453 \\
\hline $\begin{array}{l}\text { Gallus } \\
\text { gallus }\end{array}$ & AKAP8L & $\begin{array}{c}\text { A kinase (PRKA) anchor } \\
\text { protein } 8 \text {-like }\end{array}$ & 776856 & & XP_001236353 \\
\hline $\begin{array}{l}\text { Danio } \\
\text { rerio }\end{array}$ & akap8l & $\begin{array}{l}\text { A kinase (PRKA) anchor } \\
\text { protein } 8 \text {-like }\end{array}$ & 406500 & NM_213219 & NP_998384 \\
\hline
\end{tabular}

Fig. 1. Screenshot of a search result of AKAPDB. It shows 'Organism', 'Official symbol', 'Preferred Names', 'Gene ID', 'mRNA ID' and 'Protein ID'. The 'Putative zebrafish AKAP' below the table means potential zebrafish AKAP sequences. Users can search for the data based on names, Gene IDs, Protein IDs and species. 


\section{Results and Discussion}

AKAPDB contains total 500 records of proteins in all reported eukaryotic species from NCBI and the published scientific literature (Table 1). The records of AKAPDB contained 16 fields, including name, cellular localization, function, species, mRNA sequence, protein sequence, putative phosphorylation site and predicted zebrafish AKAP partial sequences.

Users can also obtain the data in accordance with names, Gene IDs, Protein IDs and species. With query, for example, the database shows the results including 'Organism', 'Official symbol', 'Preferred Names', 'Gene ID', 'mRNA ID' and 'Protein ID' (Fig. 1). In addition, users can get more information about the Domain Prediction table and Putative phosphorylation site from AKAPDB (Fig. 2).

Subcellular compartmentalization of protein kinases and phosphatases through association with AKAPs provides mechanism to control signal transduction events at specific sites within a cell (McConnachie et al., 2006).
AKAPs are a group of structurally diverse proteins with similar function of binding to the regulatory subunit of PKA within the cell (Michel et al., 2002). There are many AKAPs for the reason that many species have AKAPs with diverse forms. Regardless of the importance, our understanding of the AKAPs is restricted due to difficulty of searching on other databases. Therefore, the purpose of AKAPDB is to provide integrated understanding of AKAPs and efficient research tools to biologists.

\section{Database access}

AKAPDB can be accessed by http://plaza3.snu.ac.kr/ akapdb/ Doubts and request about AKAPDB should be mailed to waterdrop@snu.ac.kr.

\section{Acknowledgements}

This work was supported by the National Research Foundation of Korea (NRF) grant funded by the Ministry
A

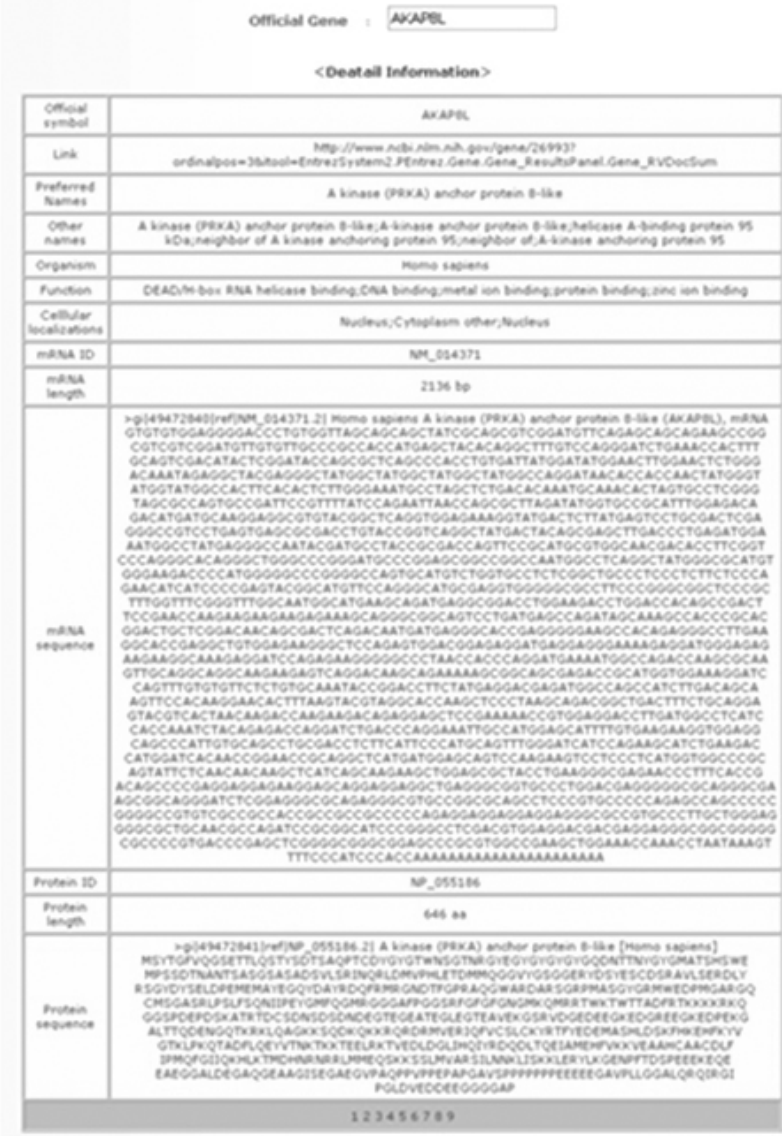

B

Domain Prediction Using SMART [UNK]

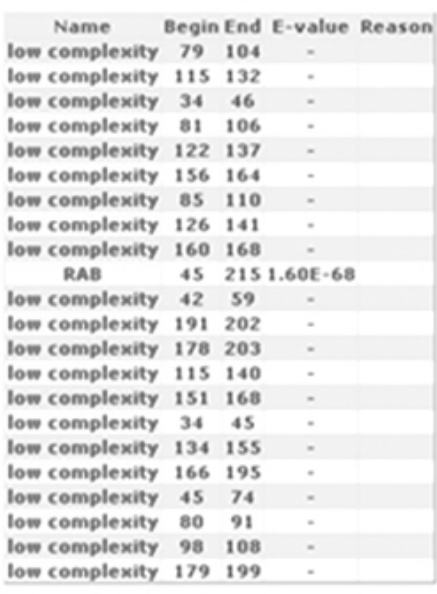

C

Put otive phosphorylotion site using GPS 2.1 (UNx)

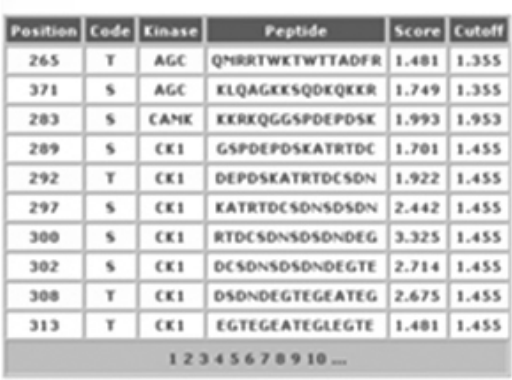

Fig. 2. Screenshot of a search result of AKAPDB. Query with the term 'AKAP8L' resulted in basic information (A), Domain Prediction table (B) and Putative phosphorylation site result (C). The database has external links to NCBI database. 
of Education, Science \& Technology (MEST) through the Creative Research Initiative Program (Grant R16-2004001010010, 2009) and the grant No. R31-2008-00010103-0 from the WCU project of the MEST and the NRF. This work was also supported by the Internship program of Korea National Institute of Health.

\section{References}

Bishop, M.J. (1999). Genetics Databases. London: Academic Press, A Harcourt Science and Technology Company.

Colledge, M., and Scott, J.D. (1999). AKAPs: from structure to function. Trends Cell Biol. 9, 216-221.

Fink, J.L., Aturaliya, R.N., Davis, M.J., Zhang, F., Hanson, K., Teasdale, M.S., Kai, C., Kawai, J., Carninci, P., Hayashizaki, Y., and Teasdale, R.D. (2006). LOCATE: a mouse protein subcellular localization database. Nucl. Acids Res. 34, D213-D217.

Francis, S.H., and Corbin, J.D. (1994). Structure and function of cyclic nucleotide-dependent protein kinases. Annu. Rev. Physiol. 56, 237-272.

Letunic, I., Doerks, T., and Bork, P. (2008). SMART 6: recent updates and new developments. Nucl. Acids Res. 37, D229-D232.

McConnachie, G., Langeberg, L.K., and Scott, J.D. (2006). AKAP signaling complexes: getting to the heart of the matter. Trends Mol. Med. 12, 317-323.

Michel, J.J.C., and Scott, J.D. (2002). AKAP mediated signal transduction. Annu. Rev. Pharmacol. Toxicol. 42, 235-257.

Nasevicius, A., and Ekker, S.C. (2000). Effective targeted gene 'knockdown' in zebrafish. Nat. Genet. 26, 216-220.
Pierleoni, A., Martelli, P.L., Fariselli, P., and Casadio, R. (2007). eSLDB: eukaryotic subcellular localization database. Nucl. Acids Res. 35, D208-D212.

Rubin, C.S. (1994). A kinase anchor proteins and the intracellular targeting of signals carried by cyclic AMP. Biochim. Biophys. Acta. 1224, 467-479.

Scott, J.D. (1991). Cyclic nucleotide-dependent protein kinases. Pharmac. Ther. 50, 123-145.

Scott, J.D., and Pawson, T. (2000). Cell communication: the inside story. Sci. Am. 282, 72-79.

Wheeler, D.L., Barrett, T., Benson, D.A., Bryant, S.H., Canese, K., Chetvernin, V., Church, DM., DiCuccio, M., Edgar, R., Federhen, S., Geer, L.Y., Kapustin, Y., Khovayko, O., Landsman, D., Lipman, D.J., Madden, T.T., Maglott, D.R., Ostell, J., Miller, V., Pruitt, K.D., Schuler, G.D., Sequeira, E., Sherry, S.T., Sirotkin, K., Souvorov, A., Starchenko, G., Tatusov, R.L., Tatusova, T.A., Wagner, L., and Yaschenko, Y. (2006). Database resources of the National Center for Biotechnology Information. Nucl. Acids Res. 34, D173-D180.

Wheeler, D.L., Church, D.M., Federhen, S., Lash, A.E., Madden, T.L., Pontius, J.U., Schuler, G.D., Schriml, L. M., Sequeira, E., Tatusova, T.A., and Wagner, L. (2003). Database resources of the National Center for Biotechnology. Nucl. Acids Res. 31, 28-33.

Wong, W., and Scott, J.D. (2004). AKAP signalling complexes: focal points in space and time. Nat. Rev. Mol. Cell Bio. 5, 959-970.

Xue, Y., and Ren, J. (2009). GPS Manual. Group-based Prediction System, Version 2.1.1. 1-24.

Xue, Y., Ren, J., Gao, X., Jin, C., Wen, L., and Yao, X. (2008). GPS 2.0: Prediction of Kinase-Specific Phosphorylation Sites in Hierarchy. Mol. Cell Proteomics 7, 1598-1608. 